\title{
PERKEMBANGAN MASYARAKAT DESA: STUDI PERUBAHAN SOSIAL MASYARAKAT GAMPONG JEUMPEUK KABUPATEN ACEH JAYA
}

\author{
Nurkhalis ${ }^{1)}$, Zulfadhli ${ }^{2}$ ) \\ ${ }^{1}$ Prodi Sosiologi, Fakultas Ilmu Sosial dan \\ Ilmu Politik, Universitas Teuku Umar \\ email:nurkhalis@utu.ac.id \\ 2 Jurusan Komunikasi dan Penyiaran \\ Islam, Fakultas Dakwah dan \\ Komunikasi, Universitas Islam Negeri \\ (UIN ) Ar-Raniry \\ email:ajzoel06@gmail.com
}

\begin{abstract}
Social change is an event (phenomenon) that is common in society, over time social change, on the one side gives positive impact (cooperation or kinship) and the other side can also be negative (disputes, individual and even conflict). The problem formulations in this study are (1). What is the social change of society that happened before and after the tsunami in Gampong Jeumpheuk, Aceh Jaya. (2). What are the factors that cause social change of society in Gampong Jeumpheuk, Aceh Jaya. The method used in this research is qualitativedescriptive method, where the process of collecting data in the field using the technique of observation and in-depth interview, previously determined informant research. Determination of informant used Purposive Sampling Technique. The theoretical basis used by the theory of symbolic interactionism, is a way of looking at individuals and social and attempts to perceive that man is the creator of the actors, the execution, and the selfdirected. The results show that the social changes of the gampong jeumpheuk community have faded (shifted) from before. It can be seen from comparing before and after tsunami and also proven from several factors that lead to economic factors, education, social and moral culture.
\end{abstract}

Keywords: Society, Village, Social Change

\section{PENDAHULUAN}

Manusia sebagai makhluk individu maupun makhluk sosial, memiliki dorongan ingin tau, ingin maju dan berkembang. Maka salah satu sarananya adalah komunikasi, karena komunikasi merupakan kebutuhan yang mutlak bagi kehidupan manusia. ${ }^{1 S e l a i n}$ itu juga diberikan berupa akal pikiran yang

${ }^{1}$ H.A.W. Widjaja, Komunikasi: Komunikasi dan Hubungan Masyarakat, (Jakarta : Bumi Aksara, 2008), hal 4 - 5. 
berkembang serta dapat dikembangkan. dalam hubungannya dengan manusia sebagai makhluk sosial, manusia selalu hidup bersama dengan manusia lainnya. Dorongan masyarakat yang dibina sejak lahir akan selalu menampakan dirinya dalam berbagai bentuk, karena itu dengan sendirinya manusia akan selalu bermasyarakat dalam kehidupannya.

Sementara itu, untuk menjalin rasa kemanusiaan yang akrab diperlukan saling pengertian sesama anggota masyarakat. Dalam hal ini faktor komunikasi memainkan peranan yang penting, apalagi bagi manusia modern. Manusia modern manusia yang cara berpikirnya tidak spekulatif tetapi berdasarkan logika dan rasional dalam melaksanakan segala kegiatan dan aktivitasnya. Kegiatan dan aktivitas akan terselenggara dengan baik melalui proses hubungan timbal balik antar manusia. ${ }^{2}$

Kerjasama suatu kegiatan yang dilakukan secara kebersamaan dari setiap lapisan masyarakat, saling bahu-membahu dan bersifat suka rela agar kegiatan yang dikerjakan dapat berjalan dengan lancar, mudah dan ringan. Sikap kebersamaan itu seharusnya dimiliki oleh seluruh elemen (lapisan) masyarakat, karena dengan adanya kesadaran setiap elemen (lapisan) masyarakat dalam melakukan setiap kegiatan dengan cara bergotong royong. Dengan demikian, segala sesuatu yang akan dikerjakan dapat lebih mudah dan cepat diselesaikan dan pastinya pembangunan di daerah tersebut akan semakin lancar dan maju. Bukan itu saja, tetapi dengan adanya kesadaran setiap elemen(lapisan) masyarakat dalam menerapkan perilaku kerjasama, maka hubungan persaudaraan dan silaturahim akan semakin erat. Dibandingkan dengan cara individualisme yang mementingkan diri sendiri, maka akan memperlambat pembangunan di suatu daerah. Karena individualisme itu dapat menimbulkan keserakahan dan kesenjangan antar masyarakat.

Sikap kerjasama merupakan budaya didalam masyarakat dan juga salah satu alat pemersatu, yang mencerminkan satu ideologi yang sama dalam kehidupan sehari-hari. Budaya juga merupakan hasil dari cipta karya manusiadi dalamnya mengandung banyak hal yang positif dan bisa memberikan warna kehidupan pada masyarakat itu sendiri.

Gampong Jeumpheuk merupakan salah satu Gampong di Kecamatan Sampoiniet Kabupaten Aceh Jaya yang menjunjung tinggi nilai-nilai budaya hasil peninggalan nenek monyang. MasyarakatGampong Jeumpheuk,adalah sebuah masyarakat yang termasuk dalam korban ganasnya musibah tsunami pada tanggl 26 Desember2004 yang lalu ini, telah lama memiliki sistem budaya yang sangat menarik untuk dicermati secara ilmiah serta memiliki nilai-nilai

${ }^{2}$ Ibid, hal 1. 
yang tinggi sebagai cerminan sekaligus bagian daripada falsafah masyarakat itu sendiri.

Dalam kehidupan sehari-hari masyarakat Jeumpheuk Kecamatan Sampoiniet tampak semakin jauh saja bergeser dari kebiasaan yang sebelumnya, dahulu masyarakat saling bekerja sama, bahu membahu secara suka rela, memiliki persatuan tanpa mengharapkan upah dari pekerjaan yang telah mereka kerjakan. Namun, hal itu mulai hilang dan lebih terlihat sikapsikap memisahkan diri serta kurang memperhatikan dalam masyarakat.

Sebagai contoh dalam aktifitas membagun dan memajukan gampong demi kepentingan bersama. Seperti merehabilitasi masjid, meunasah, membangun lapangan bola dan juga membersihkan sarana umum lainnya. Dulu mareka menganggap dengan terciptanya suatu kebersamaan maka apapun aktifitas yang telah direncanakan akan tercapai dan bisa berjalan dengan mudah seperti yang diharapkan.

Memudarnya sikap kerja sama dikalangan masyarakat gampong ini, dikarenakan telah muncul wacana masyarakat bahwa hal tersebut terjadi akibat masuknya bantuan moril dan materil dari pihak-pihak NGO (Non Government Organization) asing yang hadirnya manajemen bantuan mereka seringkali memanjakan masyarakat gampong. Misalnya, adanya manajemen strategy cash for work yang dipraktekkan oleh beberapa NGO pada masa emergency, yaitu strategi NGO tersebut membayar upah terhadap korban yang membersihkan rumahnya sendiri atau ketika relawan melakukan pekerjaan, mereka diberikan upah langsung pada sore harinya. Bukan hanya itu, namun ada juga yang melakukan model pendekatan mobilisasi massa dalam rentang waktu membangun kembali Aceh yang segalanya diukur dengan uang dan tanpa uang suatu pekerjaan tiada artinya. Praktek inilah disinyalir mematikan nilainilai kerjasama yang sudah "mendarah daging" menjadi kebiasaan masyarakat. Namun sayangnya kita hanya bisa menyalahkan pihak yang memberikan bantuan, karena memberikan bantuan dengan strategi itu. Hal itu saya rasa bisa mengatasi permasalahan kecil yang timbul.

Pasca bencana tsunami, Gampong Jeumpheuk kembali menguatnya harapan agar sikap kebersamaan yang telah lama terjalin tidak hancur serta adat, kebiasaan dan tradisi budaya masyarakat sebelumnya. Namun realita yang terjadi saat ini sangat kontradiktif ditambah lagi dengan kedatangan bala bantuan dari pihak asing ke gampong Jeumpheuk, yang mengubah nilai-nilai budaya yang telah tertanam dalam masyarakat. Sehingga menjadimasyarakat yang bekerja dengan pamrih/upah dan sulit untuk mebangunkan kembali jiwa kebersamaan dan saling membantu. 
Perubahan kebudayaan berdampak pada perubahan sosial, karena perubahan sosial terjadi akibat sistem kemasyarakatan. Proses perubahan sosial mengandung urutan perubahan yang bersifat statis dalam waktu yang lama, perubahan itu terjadi dengan sendirinya tanpa ada rencana tertentu. Hal itu berlangsung akibat adanya tindakan-tindakan masyarakat untuk menyesuaikan diri dengan keperluannya, dengan suasana dan keadaan yang muncul akibat perkembangan masyarakat. ${ }^{3}$

Memudarnya sikap kebersamaan ataupun kerja sama di masyarakat pesisir ini, maka sangat ditakutkan akan hilang bahkan lenyap dari kultural budaya masyarakat. Padahal sikap kerjasama sangat penting untuk dikembangkan, inilah sebuah dinamika yang terjadi di Gampong Jeumpheuk.

Segala persoalan di atas, menunjukkan pada perilaku dari masyarakat dan proses interaksi dalam penyampaian dan menerima informasi yang terjadi dalam masyarakat. Selain itu juga menjadi upaya mengkomunikasikan sebuah simbol, yang dianggap sesuai dari sikomunikator kepada komunikan baik secara individu maupun kelompokmasyarakat

Berkenaan dengankomunikasi yang terjadi di Gampong Jeumpheuk,selama ini telah teridetifikasi merusak sistem yang telah "mendarah daging" menjadi sebuah sistem baru dalam kehidupan masyarakatnya. Komunikasiyang sebenarnya adalah warna dari tatacara penyampaian informasi dan menerima informasi. Namun dalam prakteknya,komunikasi yang terjadi di Gampong Jeumpheuk pada saat ini telah terjadi suatu perubahan dari fenomena yang dulu sehingga dalam waktuyang akan datang sifat dan budayaan kebersamaan (kerjasama) akan luntur pada generasi-generasi muda selanjutya.Hal ini didukung pula oleh budaya modern. Maka peneliti terdorong untuk mendalami tentangkomunikasi serta perubahan masyarakat Gampong Jeumpheuk Kecamatan Sampoiniet, sehingga peneliti bisa menemukan teknik komunikasiyang mampu merubah sistem masyarakat.

Berangkat dari permasalahan diatas peneliti terdorong untuk mendalami lebih jauh lewat sebuah penelitian yang mendalam untuk mengetahui bagaimana perubahan sosial masyarakat yang terjadi sebelum dan sesudahnya tsunami diGampong Jeumpheuk Aceh Jaya dan faktor apa saja yang menyebabkan terjadinya perubahan sosial masyarakat di Gampong Jeumpheuk Aceh Jaya.

${ }^{3}$ Hajjah Bainar, Ruslan Abdul Rahman, Muhammad Jafar Anwar, Ilmu Sosial Budaya Dan Kealaman Dasar, (Jakarta : Jenki Satria, 2006),hal. 44 


\section{TINJAUANPUSTAKA}

\section{Desa atau Gampong dan Perubahan Sosial}

Desa adalah suatu hasil terpadu antara kelompok manusia dengan lingkungan, hasil dari perpaduan itu ialah suatu wujud kelompok yang nampak dimuka bumi yang ditimbulkan oleh unsur-unsur sosial budaya, ekonomi dan kultural yang saling berinteraksi. antar unsur tersebut dan hubungan kelompok juga dengan daerah lainnya. Menurut Sutardjo Kartohadikusumo, dinyatakan bahwa desa adalah suatu kesatuan hukum dimana bertempat tinggal suatu masyarakat yang berkuasa mengadakan pemerintahan sendiri.

Letak suatu desa pada umumnya agak sedikit jauh dari kota atau dari pusat keramain. Desa-desa yang letaknya pada perbatasan kota mempunyai kemungkinan berkembang yang lebih banyak daripada desa-desa perdalaman. Desa merupakan suatu wilayah yang tidak begitu dan jumlah penduduknya tidak besar juga. Dengan corak kehidupannya sangat sederhana juga mempunyaihubungan yang lebih erat dan mendalam antar sesama warganya dalam sistem kehidupan berkelompok, atas dasar kekeluargaan. ${ }^{4}$

\section{Sejarah Pemukiman Pedesaan}

Ketika mengungkapkan sejarah pemukiman desa, maka ada baiknya menguraikan secara terpisah antara makna pemukiman itu sendiri dan desa. Menurut Undang-undang No. 4 tahun 1992 tentang perumahan dan pemukiman atau permukiman, adalah bagian dari lingkungan hidup di luar kawasan lindung, baik yang berupa kawasan perkotaan maupun pedesaan yang berfungsi sebagai lingkungan tempat tinggal atau lingkungan hunian dan tempat kegiatan yang mendukung perikehidupan dan penghidupan. ${ }^{5}$

Pemukiman dapat dipahami sebagai suatu daerah yang dijadikan olehsekelompok orang sebagai tempat tinggal. Dari tempat tersebut penghuninya pergi bekerja mencari nafkah untuk memenuhi kebutuhan hasrat dan kebutuhan hidup. Pemukiman mempunyai beraneka ragam bentuk atau pola sesuai dengan kondisi lingkungan, sistem sosial yang berlaku, dan kebutuhan. Dengan bahasa lain, pola pemukiman ini ditentukan oleh karakteristik yang khas seperti faktor geografik (lembah, bukit, pinggir sungai, gurun, dataran berpadang rumput, pinggir laut atau pantai dan sebagainya), faktor sosial (saling bekerja sama, bahu membahu $239-240$

${ }^{4}$ Hartomo dan Arnicun Aziz, Ilmu Sosial Dasar, (Jakarta, Bumi Aksara, 2008), Cet. 7, hal.

${ }^{5}$ Budi Fathony, Pola Pemukiman Masyarakat Madura di pegunungan Buring, (Malang: Cita Intrans Selaras, 2009), hal. 12 
dalam mencapai tujuan bersama untuk kemajuan bersama), disamping sistem kepercayaan yang dianut para pemukim. ${ }^{6}$

Sedangkan yang dimaksud dengan desa, sebagai bentuk pemukiman dalam suatu daerah yang berada pada posisi di luar batas perkotaan, mempunyai bentuk yang berbeda-beda pula dari satu daerah dengan daerah lainnya. Meskipun demikian, dalam karakteristiknya satusama lain secara umum tidak berbeda. Di dalam literatur sosiologi dari kajian lokal dan Indonesia secara utuh, desa mendapat perbedaan atas namanya. Misalnya untuk wilayah Aceh (disebut dengan gampong), beberapa daerah di Aceh Tengah (di sebut dengan mukim). Nagari (identik namanya bagi wilayah Sulawesi), huta (kuta) di tanah Batak, ada juga penyebutan dengan ranah Minang (sebagaimana orang Minang kabau) dan lain sebagainya, termasuk Indonesia bagian timur juga mempunyai istilah khusus dalam menyebutkan kata desa. ${ }^{7}$

Pada umumnya, suatu pemukiman mempunyai beberapa ciri atau aspek tertentu yang memungkinkan ia berdiri sebagai satu pemukiman yang utuh yang disebut desa. Ciri atau aspek yang dimaksudkan di antaranya:

a. Suatu desa biasanya terdiri dari sekelompok rumah, sejumlah lumbung padi, dan gudang-gudang atau bangunan lain yang dipakai bersama. Dari lahan itu yang dimungkinkan kepemilikan secara sendiri-sendiri atau dimiliki dengan dipakai secara bersama-sama.

b. Di dekat atau disekitar desa biasanya terdapat lahan pekarangan, yang diusahakan dan mungkin dipakai sebagai lahan usaha untuk mendukung kehidupan atau kebutuhan sehari-hari.

c. Lahan usaha tani umumnya terdapat jauh atau terpisah dari pusat pemukiman.

d. Sering pula di sela-sela lahan usaha tani terdapat padang pengembalaan.

e. Di luar ciri yang tersebut di atas, dan mungkin juga sebagai batas alami satu desa dengan desa-desa lain di sekitarnya terdapat hutan semak belukar yang sering pula merupakan sumber energi bagi pemukiman desa. ${ }^{8}$

\section{Faktor Terjadinya Perubahan Sosial Masyarakat}

6Ibid..., hal. 12

7Jurnal Siti Muriah, Model Pengembangan Desa-desa Wilayah Perbatasan Secara Institut, hal. 47-49

${ }^{8}$ Bahrein T. Sugihen, Sosiologi Pedesaan, (Jakarta: RajaGrafindo Persada, 1996), hal. 73 
Perubahan sosial terjadi ketika ada kesediaan anggota masyarakat untuk meninggalkan unsur-unsur budaya dan sistem sosial lama dan mulai beralih mengunakan unsur-unsur budaya dan sistem sosial yang baru. Perubahan sosial dipandang sebagai konsep yang serba mencakup seluruh kehidupan masyarakat baik pada tingkat individual, kelompok, masyarakat, negara, dan dunia yang mengalami perubahan. Hal-hal yang penting dalam perubahan sosial menyangkut aspek-aspek sebagai berikut, perubahan pola pikir masyarakat, perubahan perilaku masyarakat, perubahan budaya materi. ${ }^{9}$

Menurut Pitrim A Sorokin, Perubahan sosialyang terjadi pada masyarakat terutama pada beberapa decade terakhir ini dapat dikatagorikan sebagai perubahan sosial yang terjadi karena disengaja (intended change)yaitu"perubahan sosial" yang terjadi karena kehendak atau dinamika masyarakat yang bersangkutan itu sendiri tanpa pengaruh dari luardan karena tidak disengaja (unintended change)yaitu "perubahan sosial" yang bersumber dari luar masyarakat atau spontan dikomunikasikan oleh pihak-pihak dari luar masyarakat.Sedangkan Menurut Selo Soemarjan, perubahan sosial adalah perubahan yang terjadi pada lembaga kemasyarakatan di dalam suatu masyarakat yang mempegaruhi sistem sosial termasuk di dalamnya nilai-nilai sikap dan pola perilaku antara kelompok masyarakat. Perubahan sosial yaitu perubahan yang terjadi dalam masyarakat atau dalam hubungan interaksi yang meliputi berbagai aspek kehidupan, akibat adanya dinamika anggota masyarakat yang bersangkutan. ${ }^{10}$

Melihat begitu luasnya cakupan perubahan sosial yang terjadi dalam masyarakat, maka untuk mengetahui suatu perubahan sosial dapat dilakukan dengan melakukan pengamatan secara cermat terhadap suatu masyarakat dan keadaan masyarakat tersebut pada masa sebelumnya (lampau), untuk memahami fenomena perbedaan keadaannya.

Pada dasarnya tidak ada satu pun manusia yang normal kehidupannya yang merasakan kepuasan terhadapa apa yang ada pada saat ini. Ketidak puasan ini didorong oleh keinginan hidup yang lebih mudah, lebih mapan, lebih baik dan sebagainya. Namun untuk mempelajari berbagai faktor penyebab perubahan sosial tidaklah cukup hanya dengan melihat gejala-gejala tersebut, ada beberapa faktor yang mengakibatkan masyarakat mengalami perubahan sosial.

${ }_{9}^{9}$ Agus Salim, Perubahan Sosial, (Yogyakarta: Tiara Wacana Yogya, 2002), hal. 20

${ }^{10}$ Wikipedia,Stratifikasi Sosial. diakses pada tanggal

http://id.wikipedia.org/wiki/Stratifikasi sosial, 
Faktor-faktor yang menyebabkan perubahan ini dapat dikelompokkan menjadi dua, yaitu: (1) faktor dari dalam masyarakat itu sendiri (faktor ekternal), dan (2) faktor yang berasal dari luar masyarakat (faktor eksternal). ${ }^{11}$ Mengenal faktor dari dalam dapat disebabkan oleh beberapa sumber, yaitu:

a. Bertambah dan berkurangnya penduduk. Pertambahan penduduk baik pendatang yang menetap di daerah tersebut. Sehingga terjadilah suatu perubahan dalam mastarakat.

b. Muncurnya penemuaan-penemuan baru dipicu oleh beberapa hal, diantaranya:

- Adanya kesadaran diri dari setiap individu atau kelompok orang akan kekurangan dalam kebudayaan.

- Kualitas para ahli (pendidikan) dalam suatu kebudayaan.

- Perangsang bagi aktivitas penciptaan (penemuan-penemuan baru) dalam masyarakat.

c. Pertentangan atau konflik dalam masyarakat sosial

Konflik sosial merupakan pertentangan yang terjadi dalam masyarakat yang hetorigen atau masyarakat majemuk yang merupakan bagian dari dinamika sosial. Konflik sosial di awali oleh perbedaan-perbadaan kepentingan, pemikiran dan pandangan yang ditemukan dalam suatu kelompok (wadah). ${ }^{12}$

Sedangkan faktor penyebab dari luar adalah di antaranya:

a. Faktor berasal dari lingkungan alam fisik yang ada disekitar manusia. Seperti bencana alam alam, gemba bumi dan gelombang pasang air laut (tsunami).

b. Gejala peperangan yang terjadi dan mengubah skruktur sosial budaya

c. Pengaruh budaya masyarakat lain, sebagaimana yang dapat dilihat pada diri anak-anak muda (generasi baru) perkotaan saat ini. ${ }^{13}$

Dan pada jurnal ini menggunakan teori Interaksionisme simbolik. Interaksionisme simbolis merupakan usaha untuk memandang bahwa manusia merupakan pencipta pelaku, pelaksanaan dan pengarah diri sendiri. Diri sendiri (the self) dalam perfektif ahli interaksionalisme simbolis adalah obyek sosial yang kita bagi dengan orang lain dalam suatu interaksi. Dengan demikian, individu pertama kali melihat dirinya sendiri adalah pada saat ia melakukan interaksi dengan orang lainmerupakan cara pandang yang

11 Soerjono Soekanto, Sosiologi Suatu Pengantar, (Jakarta: Rajawali, 1986), hal. 300

12 Elly M. Setiadi dan Usman Kolip, Pengantar Sosiologi: Pemahaman Fakta dan Gejala Permasalahan Sosial Teory Aplikasi dan Pemecahannya, (Jakarta: Kencana, 2011), hal. 624-628

${ }^{13} \mathrm{Ibid}, 629-630$ 
memperlakukan individu dan diri sosial. Kita bisa menentukan makna subyektif pada setiap obyek yang kita temui, ketimbang kita menerima apa adanya makna yang dianggap obyektif yang telah dirancang sebalumnya. Struktur sosial bisa kita lihat sebagai hasil produksi interaksi bersama, demikian pula dengan kelompok-kelompok sosial yang lain. Suatu upaya yang agak melemahkan pandangan-pandangan kaum structural fungsional yang melihat 'struktur sosial' Sebagai adanya dalam dirinya. ${ }^{14}$.

Penggunaan teori tersebut, menurut peneliti sangat sesuai dengan fokus yang peneliti lakukan. Berbicara komunikasi kelompok dengan perubahan sosial yang berlangsung di dalamnya, maka lebih tepat memperhatikan secara mikro (dimana setiap individu memiliki pengaruh dalam interaksi). Akan menarik nantinya, apabila subjektif dari setiap individu dicermati dengan seksama. Dari sikap, tindakan maupun perilaku akan dapat tersimpul bahwa apa benar atau tidaknya perubahan sosial terjadi dalam masyarakat. Oleh karena itu, peneliti merasa teori Interaksionisme Simbolik menjadi teori tepat pada penelitian ini.

\section{METODEPENELITIAN}

Setiap penelitian memerlukan metode penelitian tertentu sesuai dengan masalah yang akan diteliti. Adapun metode penelitian yang digunakan dalam penelitian ini adalah metode kualitatif untuk mendapatkan hasil penelitian yang mendekati dengan keadaan sebenarnya.Penelitian ini merupakan penelitian lapangan yang dilaksanakan dengan pendekatan deskriptif. ${ }^{15}$

Metode Penelitian yang digunakan untuk menjawab penelitian ini adalah metode penelitian kualitatif secara deskriptif. Memberikan pengertian penelitian deskriptif sebagai penelitian yang berusaha untuk menuturkan pemecahan masalah yang adaberdasarkan data, hanya memerhatikan prosesproses kejadian suatu fenomena bukan kedalaman data ataupun makna data. ${ }^{16}$

Dengan metode kualitatif ini, penulis ingin mengambarkan suatu keadaan yang terjadi pada waktu penelitianlakukan dan menjelajahi penyebab dari perubahan-perubahan tertentu, serta mengumpulkan informasi yang ada tentang keadaan-keadaan nyata sekarang. Metode ini tepat untuk menggambarkan kondisi terkini bagaimana komunikasi yang terjadi dalam masyarakat Gampong Jeumpheuk Kec. Sampoinit Kab. Aceh Jaya.

Selain itu. Dalam penelitian kualitatif, peneliti menggunakan teknik purposive sampling. Teknik ini mencakup informan-informan yang diseleksi

14.Riyadi Soeprapto, Interaksionisme Simbolik, (Malang: Averroes Press, 2009), hal. 173

${ }^{15}$ Mohammad Nasir, Metode Penelitian, (Jakarta: Ghalia Indonesia, 1985), Cet. I. hal. 65

${ }^{16}$ Burhan Bungin, Penelitian Kualitatif, (Jakarta: Kencana, 2007), hal. 146 
atas dasar kriteria-kriteria yang ditentukan oleh peneliti berdasarkan tujuan yang ingin diteliti, siapa saja yang pantas dan sesuai dijadikan informan agar memperoleh data yang akurat yang sesuai dengan tujuan penelitian. ${ }^{17}$

Informan penelitian yang dimaksud disini adalah keutjik gampong, tgk. imam, tuha pheut, sekdes gampong, ketua pemuda, kepala dusun suka damai dan ulee gunong. Juga beberapa masyarakat yang ada di Gampong Jeumpheuk Kecamatan Sampoiniet Kabupaten Aceh Jaya.

Dan pengumpulan data merupakan bagian yang paling penting dalam sebuah penelitian. Untuk mendapatkan data dilapangan penulis menggunakan teknik pengumpulan data denganwawancara dan dokumentasi. Wawancara dilakukan dengan orang-orang yang dijadikan sebagai informan, bertatap muka langsung dengan berpedoman kepada daftar pertanyaan yang telah disiapkan. Teknik ini diaplikasikan dengan mengajukan pertanyaanpertanyaan secara langsung terhadap responden yang dijadikan informan, dengan berpedoman kepada daftar pertanyaan yang telah disiapkan untuk memperoleh jawaban-jawaban yang sesuai dengan kebutuhan peneliti tentang perubahan sosial masyarakat. Informan yang diwawancarai seperangkat desa dan beberapa masyarakat gampong Jeumpheuk kabupaten Aceh Jaya. Sementara itu, dokumentasi merupakan kumpulan berkas berisi artikel/ profil atau data khusus yang mendeskripsikan keterangan pada lokasi penelitian yang peneliti lakukan.

\section{TEMUAN DANPEMBAHASAN Keadaan Penduduk}

Peduduk gampong Jeumpheuk pada umumnya terdiri dari penduduk asli suku Aceh, meskipun sebagian kecil ada juga suku Jawa, Padang, Malaya dan lain-lain. Namun jumlah mereka tidak banyak dan pada umumnya mereka termasuk dalam kaum pendatang yang berdomisili di gampong Jeumpheuk Kecamatan Sampoiniet untuk bekerja dan mencari nafkah.Menurut data tahun 2012 jumlah penduduk yang terhimpun dari beberapa dusun berjumlah 317 jiwa dengan 117 kepala keluarga.

\begin{tabular}{|c|l|c|c|}
\hline No & Dusun & Jumlah Penduduk & Persentase \\
\hline 1. & Suka Damai & 214 & $70 \%$ \\
\hline 2. & UleeGunong & 68 & $20 \%$ \\
\hline 3. & Suak Anoe & 35 & $10 \%$ \\
\hline \multicolumn{2}{|c|}{ JUMLAH } & 317 & $100 \%$ \\
\hline
\end{tabular}

Tabel 3.1. Dokumen Penduduk Gampong Jeumpheuk Kecamatan Sampoiniet. ${ }^{18}$

17 Rahmat Krisyantono, Teknik Praktis Riset, (Jakarta: Kencana, 2012), hal. 154 
Sedangkan untuk mata pencaharian masyarakat pada umumnnya masyarakat berprofesi sebagai petani dan nelayan, dan sebagian lainnya bermata pencaharian sebagai pedagang, tukang, dan penjual ikan keliling. Sebutan bagi penjual ikan itu dalam istilah orang Aceh disebut mugee, namun dari hasil tangkapan itu ada juga sekelompok pembeli yang langsung membeli ikan-ikan tersebut sendiri tanpa perantaraan mugee, ada juga yang bermata pencaharian sebagai peternak seperti beternak sapi, kambing dan kerbau. Bagi peternak dapat memanfaatkan tanah kosong yang ditumbuhi padang rumput yang luas nan hijau sehingga menguntungkan bagi masyarakat yang beternak dan ada juga masyarakat yang berprofesi sebagai wiraswasta.

\begin{tabular}{|c|l|c|c|}
\hline No & Jenis Mata Pencaharian & Jumlah & Persentase \\
\hline 1. & Nelayan & 193 & $60 \%$ \\
\hline 2. & Petani & 78 & $20 \%$ \\
\hline 3. & Pedagang & 27 & $10 \%$ \\
\hline 7. & Lain-lainnya & 19 & $10 \%$ \\
\hline \multicolumn{2}{|c|}{ Jumlah } & 317 & $100 \%$ \\
\hline
\end{tabular}

Tabel 3.2. Dokumen Mata Pencaharian Penduduk ${ }^{19}$

Dari tabel di atas dapat disimpulkan, bahwa manyoritas mata pencaharian masyarakat gampong Jeumpheuk adalah nelayan dengan jumlah persentasi sebanyak 60\%. Dari angka tersebut membuktikan bahwa dominan mata pencaharian mereka pada kawasan pesisir yakni melaut.

\section{A. Perubahan Sosial Sebelum dan Sesudah Tsunami}

Perubahan sosial merupakan situasi dan kondisi yang lazim terjadi dalam suatu kehidupan bermasyarakat. Dari perubahan sosial dalam masyarakat terutama di kawasan Gampong Jeumpheuk Kabupaten Aceh jaya, apabila diamati lebih lanjut maka akan terlihat beberapa berubahan yang terjadi pada saat sebelum dan sesudah tsunami. Juga bisa dilihat dari beberapa beberapa faktor yang ditemukan.

Informan yang ingin diwawancara dalam penelitian ini telah terpilih, sebagian berjumlah 4 (empat) orang. Diantaranya keutjik gampong, tgk imam, tuha pheut dan kepala dusun suka damai diambil dari perubahan sosial masyarakat yang terjadi sebalum dan sesudanya tsunami di gampong Jeumpheuk. Kemudian 4 (empat) ditemukan dari mereka akibat faktor-faktor atas perubahan sosial yang terjadi di masyarakat Jeumpheuk. Simak beberapa

\footnotetext{
18 Data gampong Jeumpheuk, tahun 2012

${ }^{19}$ Data Arsip gampong Jeumpheuk
} 
deretan hasil wawancara mengarah kepada perubahan sosial masyarakat gampong Jeumpheuk,

"Melihat dari fenomena yang terjadi,dulu masyarakat Gampong Jeumpheuk lebih erat ikatan yang terjalin, saling bahu-membahu (bersatu) dan bekerja sama dalam membangun sarana-sarana yang ada digampong. Seperti, membangun masjid, meunasah, lapangan bola dan saranan lainnya. Untuk mencapai tujuan bersama, masyarakat Gampong jeumpheuk sering mengadakat mufakat (musyawarah) agar semua masyarakat bisa ikot serta disetiap kegiatang yang dilaksanakan di gampong jeumpheuk."

\section{Tambahnya,}

"fenomena sekarang, minat masyarakat sudah kurang dalam hal berkerja sama, bermusyawarah dalam membangun dan mensejatrakan Gampong. Padahal itu yang kita lakukan semua untuk kepentingan masyarakat juga dan kepentingan kita juga selaku warga gampong. Ini juga disebabkan oleh ekonomi dan pergaulan." 20

Dengan dampak perubahan sosial yang terjadi secara individu maupun kelompok dalam masyarakat gampong jeumpheuk, sebagai Keutjik gampong sudah berupaya membina kembali persatukan dan kesadaran masyarakat untuk membangun kerjasama dalam diri masyarakat itu sendiri, baik individu maupun kelompok masyarakat. Sehingga ikatan (silaturrahmi) antar sesama masyarakat selalu terjaga dan harmonis.

“Kondisi sekarang (sesudah tsunami), masyarakat Gampong Jeumpheuk sudah jarang melakukankan musyawarah. Pada dasarnya musyawarah itu untuk mencapai tujuan yang sama apa yang ingin buat agar tercapai tanpa pemecahan antara individu-individu. Apalagi dengan bekerja sama (gotong royong) itu sudah kurang, mungkin disebabkan individuindividu tadi.

Kondisi dulu (sebelum tsunami). Misalnya, ketika ada acara adat yaitu kendurie blang (sawah) anak muda, orang tua, bersama-sama membantu mempersiapkan acara, artinya ke inginan kerja sama itu masih kuat. Bagi masyarakat aceh musyawarah, kerja sama (gotong

${ }^{20}$ Hasil Wawancara dengan bapak Taufik (Keucik/Kepala Desa gampong Jeumpheuk) pada tanggal 09 Juni 2016 
royong) bukanlah sesuatu yang asing, melainkan watak dan kepribadian mareka." 21

"Saya melihat dari warga gampong kita sekarang dengan sebelum tsunami sudah banyak berbeda "sebelum tsunami" warga sangat inisiatif melakukan kerja sama. Dengan dilakukan kerja sama juga meringan kan ekonomo masyarakat gampong dalam pembangunan. Seperti dulu pembangunan mesjid kita melakukan dengan gotong royong bersama, saling membantu dan menyumbang. "sesudah tsunami" kita lihat dari pembanguna mesjid sekarang, ketika ingin buat pagar mesjid kita harus menunggu dana dari intansi-intansi terkait baru bisa membangunnya. Karna telah bergantungan dengan dana itu tanpa ada upaya mencari jalan lain." 22

"Menurut saya keadaannya sudah berbeda dengan keadaan sebelum tsunami, sebelum tsunami warga sangat gemar bekerjasama dan bergotong royong membersihkan sarana-sarana umum digampong. Mareka sering melakukan gotong royong seminggu sekali, paling kuran sebulan sekali pasti ada. Sekarang sesudah tsunami jangankan seminggu sekali sebulan sekalipun jarang ada, jika ingin melaksanakan suatu kegiatan baru bergotong royong dan itu pada saat mengadakan kegiatan tertentu saja. Itupun saya lihat tidak semua masyarakat yang hadir" 23

Dari beberapa hasil wawancara di atas sudah terlihat bahwa masyarakat gampong Jeumpheuk sudah mengalami pergeseran, baik itu disadari maupun tidak. Sehingga pergeseran ini menyebabkan perubahan sosial dalam masyarakat. Dari fenomena masyarakat yang dulu suka bermusyawarah dan berkerja lama, lama-kelamaan sifat kebersamaan itu sudah memudar dan menjadi masyarakat yang individualisme tanpa memperhatikan kepertingan bersama.

\section{B. Faktor-Faktor Perubahan Sosial Yang Terjadi Dalam Masyarakat Gampong Jeumpheuk}

Terkait dengan adanya perubahan sosial yang terjadi di lokasi penelitian, dari hasil temuan peneliti di lapangan memperoleh adanya beberapa faktor penyebab terjadinya perubahan sosial. simak penuturan dari wawancara dengan beberapa informan berikut, Juni 2016

${ }^{21}$ Hasil Wawancara Bustami YN (Tuha Pheut gampong Jeumpheuk ) pada tanggal 17

22 Hasil Wawancara dengan Tgk. Zainon (Tengku Imam gampong Jeumpheuk), pada tanggal 20 Juni 2016

${ }^{23}$ Hasil wawncara dengan Iswadi (kepala dusun suka damai gampong Jeumpheuk pada), pada tanggal 22 Juni 2016 
"Menurut saya melihat dari faktornya, salah satunya adalah ekonomi yang terjadi di Gampong. Setelah terjadinyan musibah tsunami masyarakat sering mendapatkan bantuan dan sumbangan dari instansi terkait (NGO). Tanpa harus bekerja keras, mereka juga akan mendapatkan bantuan dan sumbangan tersebut, juga ada yang memberikan modal usaha sehingga membuat masyarakat berharap. Terkadang menjadi malas melakukan usaha. Apalagi untuk bekerja sama membersihkan atau membangun sarana-sarana dalam gampong. Sehingga menjadi orang-orang yang mengharapkan upah atas setiap pekerjaan-perkerjaan yang dilakukan." 24

Dari apa yang dituturkan oleh informan menjadi bukti faktor ekonomi berasal dari bantuan pasca bencana dan gempa Tsunami menjadikan selanjutnya perubahan sosial masyarakat kian berorientasi kepada sisi ekonomi atau bisa dikatakan bahwa segala hal akan dikerjakan seseorang di gampong tersebut tatkala diberikan upah (pembayaran).

“Kemudian, peneliti menemukan faktor lain, "Menurut saya, apabila kita perhatikan pada anak muda saat ini termasuk anak remaja. Mareka telah menyamakan pergaulan dengan dikota-kota, pergaulan yang bermewah-mewahan dan juga telah mengikuti pergaulan luar, seperti yang sering dilihat di TV, Majalah dan media lainnya. Sebagian anak muda lebih mengutamakan pergaulan dari pada pendidikan, inilah yang saya lihat sekarang." 25

Singkat kata faktor yang satu ini, peneliti melihat masyarakat semakin terpengaruh atau menular budaya pergaulan yang terlihat melalui media massa, sehingga ke tertular dari seseorang kepada yang lainnya dengan proses pergaulan di masyarakat dalam hal ini masyarakat desa Jeumpheuk. Faktor pergaulan ini bisa dilihat dari apa yang diungkapkan oleh informan, sebagai Ketua Pemuda di desa Jeumpheuk. Apa yang disampaikan, bisa dikatakan faktor pergaulan menjadi pemicu yang mengambil tempat pada perubahan sosial yang terjadi di desa Jeumpheuk.

"Saya lebih melihat faktor di bidang pendidikan. Kenapa, karena saya bisa melihat waktu saya kuliah dulu diantara kami tidak ada persaingan dalam bidang pendidikan pada saat kami di telah digampong. Apapun yang telah saya dan kawan-kawan dapatkan, kami akan berbagi digampong dan sama-sama tujuan kami untuk menyatukan masyarakat

${ }^{24}$ Hasil Wawancara dengan Idris (Kepala dusun ulee gunong gampong Jeumpheuk), tanggal 23 Juni 2016

${ }^{25}$ Wawancara dengan Musliadi. Z (Ketua pemuda gampong jeumpheuk ) pada tanggal 9 Juli 2016 
dalam membangun gampong. Dengan cara bagaimana kita semua untuk menyatukan masyarakat dan mensejatrakan masyarakat dalam gampong ini. Berbeda dengan kondisi sekarang, mareka hanya bersaing dalam bidang pendidikan namun tidak tau untuk mengembangkan ilmu mereka dan berbagi dengan masyarakat." 26

Faktor pendidikan juga menjadi faktor mempengaruhi perubahan sosial yang terjadi di masyarakat Jeumpheuk. Dimana terlihat kecendrungan bagi mereka yang telah menuntut ilmu lebih tinggi akan tampak memisahkan diri dengan orang yang pendidikan lebih rendah. Ditambahkan pula oleh Teuku Muntasir, pendidikan, budaya pergaulan dan ekonomi yang kedua menjadi faktor yang disampaikan berpengaruh terhadap perubahan masyarakat desa Jeumpek. Seperti apa yang disampaikannya,

"Menurut saya, penyebab perubahan di antaranya ekonomi, karena apapun sarana yang ingin dibangun dalam gampong membutuhkan dana dan pergaulan dan pendidikan. mareka melihat pergaulan yang setara dengan mareka, sama halnya dibidang pendidikan." 27

Adapun yang menjadi faktor lain yang peneliti temukan dengan perubahan sosial masyrakat di desa Jeumphek, yakni faktor sosial, seperti apa yang disampaikan Azhari yang merupakan masyarakat desa (gampong) Jeumpheuk,

"Saya lebih setuju menyebutkan salah satu penyebab kuatnya adalah faktor sosial, karena kurangnya rasa kebersamaan dan saling memiliki dalam masyarakat, disebabkan oleh sikap individu yang mementingkan diri sendiri. Jika watak individu, namun sangat lah susah untuk membangun gampong jeumpheuk." 28

"Saya melihat faktor utamanya kekemauan dari masyarakatnya kurang, mareka tidak menyadari bagaimana peran selaku warga dalam gampong, dalam melakukan aktifitas bersama disitu kita tidak mengharapkan upah sedikitpun, disitu kita juga meluangkan waktu, tenaga dan pikiran kita untuk kepentingan bersama. Kepentingan itu adalah untuk membangun dan men sejaterakan gampong. Memelihara,

${ }^{26}$ Hasil wawancara dengan Samsinar (Warga gampong Jeumpheuk) pada tanggal 27 2016

28 Hasil wawancara dengan Azhari (warga gampong Jeumpheuk) pada tanggal 19 Agustus 2016 
menjaga saranan yang telah ada selalu utuh dan bisa dipakai oleh masyarakat kita sendiri khususnya" 29

Dari apa yang sudah peneliti peroleh beberapa informan di atas, bahwa memang benar adanya faktor perubahan soaial dalam masyarakat gampong Jeumpheuk. Di antaranya ekonomi, pendidikan, budaya pergaulan dan moral (kepentingan) menjadi hal yang selama ini terjadi dalam perubahan sosial.

\section{KESIMPULAN}

Setelah memperhatikan dengan seksama, dimulai dari latar belakang penelitian sampai dengan laporan hasil pada penelitian ini. Maka ada beberapa poin kesimpulan yang bisa peneliti dapatkan dalam penelitian ini adalah;

Pertama, adanya beberapa faktor yang mempengaruhi perubahan sosial masyarakat desa Jeumpek terdiri dari ekonomi, pendidikan, budaya pergaulan dan kondisi sosial. Kesemua faktor tersebut muncul pasca tsunami. Perubahan menjadi keadaan yang biasa terjadi dalam suatu masyarakat desa maupun kota tidak terkecuali dengan apa yang terjadi di masyarakat Desa Jeumphek

Kedua, mengenai sisi positif dan negatif dari perubahan sosial yang terjadi di masyarakat desa Jeumphek. Sisi positif ialah dianggap sebagai pelajaran untuk selanjutnya dipahami sehingga saat merasa tidak erat lagi akan kembali mempererat demi mewujudkan masyarakat yang sejahtera dan bersahabat. Sedangkan pada sisi negatif, perubahan sosial menjadi ancaman bagi keadaan masyarakat yang tidak peduli satu sama bahkan apabila perubahan tidak tampak sehat bisa saja akan menyebabkan konflik.

\section{DAFTAR KEPUSTAKAAN}

\section{$\underline{\text { Buku }}$}

Agus Salim. 2002. Perubahan Sosial. Yogyakarta: Tiara Wacana Yogya

Bahrein T. Sugihen. 1996. Sosiologi Pedesaan. Jakarta: RajaGrafindo Persada,

Budi Fathony. 2009.Pola Pemukiman Masyarakat Madura di pegunungan Buring. Malang: Cita Intrans Selaras

Burhan Bungin. 2007. Penelitian Kualitatif. Jakarta: Kencana

Elly M. Setiadi dan Usman Kolip. 2011.Pengantar Sosiologi: Pemahaman Fakta dan Gejala Permasalahan Sosial Teori Aplikasi dan Pemecahannya. Jakarta: Kencana

${ }^{29}$ Hasil wawancara dengan Rasmadi (sekdes gampong Jeumpheuk) pada tanggal 28 
H.A.W. Widjaja. 2008. Komunikasi: Komunikasi dan Hubungan Masyarakat. Jakarta : Bumi Aksara,

Hajjah Bainar, Ruslan Abdul Rahman, Muhammad Jafar Anwar. 2006.Ilmu Sosial Budaya Dan Kealaman Dasar. Jakarta : Jenki Satria

Hartomo dan Arnicun Aziz. 2008. Ilmu Sosial Dasar. Jakarta, Bumi Aksar

Mohammad Nasir. 1985.Metode Penelitian. Jakarta: Ghalia Indonesia

Riyadi Soeprapto. 2009. Interaksionisme Simbolik. Malang: Averroes Press

Soerjono Soekanto. 1986.Sosiologi Suatu Pengantar. Jakarta: Rajawali

\section{Jurnal dan Website}

Jurnal Siti Muriah. 2011. Model Pengembangan Desa-desa Wilayah Perbatasan Secara Institut, hal. 47-49

Wikipedia,Stratifikasi Sosial.diakses pada tanggal tanggal 20 Juli 2016 http://id.wikipedia.org/wiki/Stratifikasi sosial, 